\title{
PENGETAHUAN IBU TENTANG MATERI PERAWATAN MASA NIFAS DALAM BUKU KIA DENGAN KETERATURAN KUNJUNGAN NIFAS
}

\author{
Ika Yudianti, Ari Kusmiwiyati, Puji Rahayu \\ Kementerian Kesehatan Politeknik Kesehatan Malang Jurusan Kebidanan
}

\begin{abstract}
Maternal And Child Health-Book, Women's Knowledge, Postnatal Visit. In 2015 , the national coverage of postnatal visit only reached $87.06 \%$ of the target $95 \%$. The mother's and child's health book (MCH book) contains comprehensive medical records and information, including postpartum care. If the KIA's book material is read and understood by the mother, her knowledge will increasing, so we can expect her to be willing to do the postpartum visit according to the government's program. This research aimed to learn about the correlation between postnatal woman's knowledge on postnatal services and her postnatal visit regularity. Design used was correlational study with cross sectional approach. The population was all post-natal women who have MCH book at a private midwife practice in May - June 2017 of total 35 women. Samples taken by simple random technique. Data collection tool used was questionnaire and $\mathrm{MCH}$ book. The result showed that a small amount of respondents with good knowledge about postnatal care $(28,1 \%)$ done postpartum visit in accordance with the government's program. Women with less knowledge level (18,8\%), few of them (3.1\%) made postnatal visits in accordance with the program. Chi-square analysis obtained $\rho$ value (0.001) that means less than $\alpha(0,05)$, so the null hypothesis rejected. Hence, there was correlation between postnatal woman's knowledge on postnatal services and her postnatal visit regularity. The results of the study said that most of the well-informed women about postnatal services will do postpartum visits according to government programs. Postpartum women need to be motivated to read postpartum care materials in maternal and child health-book.
\end{abstract}

Keyword : Maternal And Child Health-Book, Women's Knowledge, Postnatal Visit

Abstrak: Buku KIA, Pengetahuan Ibu, Kunjungan Nifas. Tahun 2015 cakupan pelayanan nifas tingkat nasional hanya tercapai sebesar $87,06 \%$ dari target $95 \%$. Buku KIA berisi catatan dan informasi kesehatan yang lengkap, termasuk pelayanan nifas. Jika materi buku KIA dibaca dan dipahami ibu, maka akan menambah pengetahuannya sehingga diharapkan ibu melakukan kunjungan nifas sesuai program pemerintah. Tujuan penelitian ini adalah untuk mengetahui hubungan antara pengetahuan ibu tentang perawatan masa nifas dan kunjungan nifas. Desain penelitian analitik korelasional dengan pendekatan Cross sectional. Sampel adalah ibu nifas yang memiliki Buku KIA di BPM S Kab. Malang pada Mei - Juni 2017 sebanyak 32 orang. Teknik sampling secara acak sederhana dengan undian. Instrumen penelitian menggunakan kuesioner dan Buku KIA. Hasil penelitian didapatkan sebagian kecil responden dengan pengetahuan baik $(28,1 \%)$ telah melakukan kunjungan nifas sesuai dengan program, responden dengan tingkat pengetahuan cukup sangat sedikit $(18,8 \%)$ yang melakukan kunjungan nifas sesuai program, sedangkan tingkat pengetahuan kurang sangat sedikit 
$(3,1 \%)$ yang melakukan kunjungan nifas sesuai dengan program. Uji hipotesis menggunakan Chi-square didapat nilai $\rho$ value $(0,001)<\alpha(0,05)$, kesimpulannya adalah ada hubungan antara pengetahuan ibu nifas tentang materi perawatan masa nifas dalam buku KIA dengan keteraturan kunjungan nifas. Ibu dengan pengetahuan yang baik tentang perawatan masa nifas cenderung akan melakukan kunjungan nifas dengan teratur, oleh sebab itu ibu nifas perlu dimotivasi untuk membaca materi perawatan masa nifas dalam Buku KIA.

Kata Kunci: Buku KIA, Pengetahuan Ibu, Kunjungan Nifas

\section{PENDAHULUAN}

Masa nifas (puerperium) adalah masa yang dimulai setelah kelahiran plasenta dan berakhir ketika alat-alat kandungan kembali seperti keadaan sebelum hamil. Asuhan masa nifas diperlukan karena masa ini merupakan masa kritis bagi ibu maupun bayinya. Penyulit yang sering terjadi pada ibu nifas yaitu perdarahan, infeksi dan depresi masa nifas (Prawirohardjo, 2012). Supaya dapat dilakukan skrining atau deteksi dini terhadap penyulit-penyulit pada masa nifas maka setiap ibu nifas tanpa terkecuali dianjurkan untuk melakukan kunjungan nifas guna memperloleh pelayanan masa nifas sesuai standar (Dewi, 2011).

Pemerintah telah melakukan upaya deteksi dini penyulit pada masa nifas dengan melakukan pemantauan jumlah kunjungan ibu nifas sebanyak minimal 3 kali. Kunjungan nifas pertama dilakukan pada 6 jam sampai 3 hari setelah persalinan, dan kunjungan nifas kedua dalam rentang waktu 4-28 hari setelah persalinan, kunjungan nifas ke tiga dalam rentang waktu 29-42 hari setelah persalinan. Berdasarkan Kepmenkes 828/MENKES /SK/IX/2008 tentang Petunjuk Teknis Standar Pelayanan Minimal Bidang Kesehatan di Kabupaten/Kota, pada tahun 2015 target cakupan pelayanan nifas tingkat nasional sebesar 95\%, namun pada kenyataannya target cakupan ini hanya tercapai sebesar $87,06 \%$ (Dinkes Kota Malang, 2015). Fenomena ini menunjukkan masih kurangnya kunjungan ibu nifas dibandingkan dengan cakupan program yang ditetapkan.

Kunjungan nifas merupakan salah satu bentuk perilaku kesehatan. Standar pelayanan pada masa nifas antara lain meliputi: pemeriksaan fisik, senam nifas, pemberian vitamin $\mathrm{A}$, penanganan masalah umum dan khusus, perencanaan dan pelayanan Keluarga Berencana (Depkes RI, 2009).

Faktor yang dapat mempengaruhi kunjungan masa nifas yaitu motivasi, pendidikan, peran keluarga serta pengetahuan (Buhari \& Hutagaol, 2015). Pengetahuan ibu tentang masa nifas salah satunya dapat diperoleh dari buku KIA yang merupakan alat untuk mendeteksi secara dini adanya gangguan atau masalah kesehatan ibu dan anak. Selain itu, buku KIA dapat digunakan sebagai alat komunikasi, dan penyuluhan tentang informasi yang penting bagi ibu, keluarga serta masyarakat mengenai pelayanan kesehatan ibu dan anak. Salah satu isi buku KIA adalah catatan dan informasi mengenai cara perawatan ibu nifas, tanda bahaya nifas, keluarga berencana (KB), serta jadwal dan catatan kapan ibu harus 
melakukan kunjungan nifas ke tenaga kesehatan (Depkes RI, 2012).

Buku Kesehatan Ibu dan Anak (KIA) pertama kali diuji cobakan pada tahun 1993 di Kotamadia Dati II Salatiga jawa Tengah, dalam rangka kerjasama Departemen Kesehatan bersama dengan JICA melalui Community Based Family Planning and Mother and Child Health Project (Proyek KB-KIA). Penggunaan buku KIA telah meluas sehingga pada tahun 2006 seluruh provinsi telah menggunakan buku KIA. Buku Kesehatan Ibu dan Anak (Buku KIA) revisi tahun 2015 berisi catatan dan informasi yang lengkap sehingga jika semua materi pada buku ini dibaca dan dipahami oleh ibu, akan mendapat menambah pengetahuannya. Manfaat kepemilikan buku Kesehatan Ibu dan Anak (KIA) selain meningkatkan pengetahuan ibu juga dapat mempunyai catatan kesehatan yang lengkap, sejak hamil sampai dengan anak berumur 6 tahun (Depkes RI, 2008).

Hasil studi pendahuluan yang dilakukan di BPM S Jabung Kabupaten Malang, menunjukkan bahwa sebagian besar ibu nifas melakukan kunjungan nifas pada 6 jam - 3 hari (100\%), 4-28 hari $(80 \%)$, dan $29-42(70 \%)$. Hal ini menunjukkan masih kurangnya pengetahuan ibu nifas tentang pentingnya kunjungan masa nifas sebagai upaya untuk mencegah penyulit pada masa nifas. Kepemilikan buku KIA pada ibu nifas di BPM S (100\%).

Penelitian ini diharapkan dapat menjadi sumber informasi awal dalam menemukan solusi yang tepat untuk mengatasi target kunjungan masa nifas yang masih belum memenuhi target tersebut.

\section{METODE PENELITIAN}

Desain penelitian yang digunakan dalam penelitian ini adalah desain analitik korelasional dengan pendekatan cross sectional (Arikunto, 2006).

Populasi yang digunakan dalam penelitian ini adalah seluruh ibu nifas yang memiliki Buku KIA dan berada pada hari ke-42 masa nifas di BPM S pada bulan Mei - Juni 2017 sebanyak 35 orang.

Sampel yang digunakan dalam penelitian ini adalah sebagian ibu nifas yang memiliki Buku KIA di BPM S bulan Mei - Juni 2017 dan memenuhi kriteria inklusi sebanyak 32 orang.

Teknik pengambilan sampel dalam penelitian ini adalah dengan menggunakan Simple Random Sampling dengan cara undian.

Kriteria inklusi pada penelitian ini adalah ibu nifas yang:

a. Tercatat di register BPM S

b. Memiliki Buku KIA

c. Dapat membaca dan menulis

d. Berada di hari ke-42 nifas

Variabel independen adalah pengetahuan ibu tentang materi perawatan masa nifas dalam Buku KIA. Yang dimaksud dengan pengetahuan ialah segala informasi yang diketahui ibu tentang materi perawatan masa nifas dalam Buku KIA. Kategori pengetahuan dikelompokkan menjadi: baik (persentase jawaban benar 76- 100\%), cukup (persentase jawaban benar 56-75\%), dan kurang (persentase jawaban benar < $56 \%)$.

Variabel dependen dalam penelitian ini adalah keteraturan kunjungan ibu nifas. Yang dimaksud dengan keteraturan kunjungan ibu nifas adalah distribusi kontak antara responden dengan bidan untuk mendapatkan pelayanan ibu nifas yang dimulai sejak 
enam jam setelah lahirnya plasenta hingga hari ke-42. Keteraturan kunjungan nifas dikategorikan menjadi:

1) Teratur, yaitu minimal 3 kali selama masa nifas dan distribusinya sesuai

2) Tidak teratur, yaitu kunjungan nifas $<3$ kali selama masa nifas, atau distribusinya tidak sesuai dengan jadwal program kunjungan nifas.

Pengumpulan data dilakukan

dengan cara:

1) Menyusun kuesioner tertutup dengan opsi jawaban tersedia untuk menilai pengetahuan lalu melakukan uji validitas dan reliabilitas instrumen. Tersedia delapan belas pertanyaan yang dinyatakan valid dan reliable dengan nila alpha cronbach 0,86 .

2) Memastikan kembali keberadaan ibu nifas sesuai kriteria inklusi

3) Melakukan pendekatan pada ibu nifas sesuai inklusi yang melakukan kunjungan di lokasi penelitian, bila ibu nifas tidak melakukan kunjungan maka peneliti melakukan kunjungan rumah.

4) Menjelaskan maksud serta tujuan penelitian.

5) Memastikan legalitas persetujuan dengan penandatanganan surat persetujuan menjadi responden

6) Menjelaskan pada ibu cara mengisi kuesioner

7) Memberikan pada ibu alat tulis dan lembar kuesioner yang harus diisi oleh ibu

8) Memastikan kuesioner telah di isi dengan benar dan lengkap.

9) Meminjam buku KIA ibu dan menghitung kunjungan nifas ibu yang sudah dilakukan dan mencatat dimana ibu melakukan kunjungan. dengan jadwal program kunjungan masa nifas:

a. 6 jam - 3 hari 1 kali kunjungan

b. 4 - 28 hari 1 kali kunjungan

c. 29 - 42 hari 1 kali kunjungan

\section{HASIL PENELITIAN}

\section{Tabel 1}

Karakteristik Berdasarkan Usia, Pendidikan, dan Pekerjaan

\begin{tabular}{llcc}
\hline \multicolumn{2}{c}{ Karakteristik } & $\begin{array}{c}\text { Frekuensi } \\
(\mathbf{f})\end{array}$ & $\begin{array}{c}\text { Persentase } \\
(\mathbf{\%})\end{array}$ \\
\hline Usia & $<20$ & 14 & 42,4 \\
(tahun) & $20-35$ & 11 & 33,3 \\
& $>35$ & 7 & 21,2 \\
& Jumlah & 32 & 100 \\
\hline Pendidikan & SD & 8 & 25,0 \\
\cline { 2 - 4 } & SMP & 16 & 50,0 \\
& SMA & 7 & 21,9 \\
& PT & 1 & 3,1 \\
& Jumlah & 32 & 100 \\
\hline Pekerjaan & Bekerja & 22 & 68,8 \\
& Tidak & 10 & 31,3 \\
& Bekerja & & \\
& Jumlah & 32 & 100 \\
\hline
\end{tabular}

Tabel 1 menunjukkan bahwa

hampir separuh responden $(42,4 \%)$

berusia $<20$ tahun, dimana usia tersebut termasuk usia reproduksi yang kurang sehat. Diketahui pula bahwa separuh responden $(50,0 \%)$ berpendidikan SMP, lebih rendah daripada wajib belajar yang ditetapkan oleh pemerintah yaitu 12 tahun (SMA). Berdasarkan tabel 1 diketahui pula bahwa lebih dari separuh responden $(68,8 \%)$ bekerja di luar rumah untuk mencari nafkah. 
Tabel 2

Pengetahuan Tentang Perawatan Masa Nifas dalam Buku KIA

\begin{tabular}{ccc}
\hline \multirow{2}{*}{ Tingkat Pengetahuan } & \multicolumn{2}{c}{ Ibu Nifas } \\
\cline { 2 - 3 } & (f) & \% \\
\hline Baik & 10 & 31,3 \\
Cukup & 11 & 34,4 \\
Kurang & 11 & 34,4 \\
\hline Jumlah & $\mathbf{3 2}$ & $\mathbf{1 0 0 , 0}$ \\
\hline
\end{tabular}

Berdasarkan tabel 2 diketahui bahwa tingkat pengetahuan ibu nifas tentang perawatan masa nifas dalam buku KIA berada pada kategori baik, cukup, dan kurang, dengan perbedaan proporsi yang tidak terlalu jauh yaitu antara 31,2$34,4 \%$.

Tabel 3

Keteraturan Kunjungan Nifas

\begin{tabular}{ccc}
\hline Kunjungan & \multicolumn{2}{c}{ Ibu Nifas } \\
\cline { 2 - 3 } Nifas & Frekuensi (f) & \% \\
\hline Teratur & 16 & 50,0 \\
Tidak & 16 & 50,0 \\
Teratur & & \\
\hline Jumlah & $\mathbf{3 2}$ & $\mathbf{1 0 0 , 0}$ \\
\hline
\end{tabular}

Tabel 3 memberikan gambaran bahwa ibu nifas yang melakukan kunjungan nifas teratur dan tidak teratur memiliki proporsi yang sama yaitu $(50,0 \%)$.

\section{Tabel 4}

\begin{tabular}{|c|c|c|c|c|c|c|}
\hline \multicolumn{7}{|c|}{$\begin{array}{l}\text { Pengetahuan Materi Nifas dalam Buku } \\
\text { KIA dan Kunjungan Nifas }\end{array}$} \\
\hline \multirow[t]{3}{*}{ Pengetahuan } & \multicolumn{4}{|c|}{ Kunjungan Nifas } & \multirow{2}{*}{\multicolumn{2}{|c|}{$\begin{array}{c}\text { Total } \\
\text { Responden }\end{array}$}} \\
\hline & \multicolumn{2}{|c|}{ Teratur } & \multicolumn{2}{|c|}{$\begin{array}{c}\text { Tidak } \\
\text { Teratur }\end{array}$} & & \\
\hline & $\mathrm{f}$ & $\%$ & $\mathrm{f}$ & $\%$ & $\mathrm{f}$ & $\%$ \\
\hline Baik & 9 & 28,1 & 1 & 3,1 & 10 & 31,3 \\
\hline Cukup & 6 & 18,8 & 5 & 15,6 & 11 & 34,4 \\
\hline Kurang & 1 & 3,1 & 10 & 31,3 & 11 & 34,4 \\
\hline Jumlah & 16 & 5 & 16 & $\mathbf{5 0 , 0}$ & 32 & 100.0 \\
\hline
\end{tabular}

Tabel 4 menunjukkan bahwa persentase responden terbesar yang melakukan kunjungan nifas secara teratur atau sesuai dengan program yang ditetapkan Kementerian Kesehatan RI, berasal dari ibu nifas yang memiliki pengetahuan baik tentang materi perawatan masa nifas dalam buku KIA $(28,1 \%)$, sebaliknya, persentase responden terbesar yang tidak melakukan kunjungan nifas secara teratur, berasal dari ibu nifas yang memiliki pengetahuan kurang $(31,3 \%)$.

Hasil uji statistik menggunakan Chi-square didapat nilai $r 13.855$ dengan $\rho$ value $(0,001)$, sehingga $\mathrm{H} 0$ ditolak. Hasil tersebut menunjukkan ada hubungan antara pengetahuan ibu nifas tentang materi perawatan masa nifas dalam buku KIA dengan keteraturan kunjungan nifas.

\section{PEMBAHASAN}

Hasil penelitian menunjukkan bahwa sebagian kecil ibu yang memiliki pengetahuan baik tentang perawatan masa nifas dalam buku KIA (31,3\%), sedangkan ibu yang memiliki pengetahuan cukup dan kurang tentang perawatan masa nifas dalam buku KIA sebagian kecil responden $(34,4 \%)$. Pengetahuan ibu tentang cara perawatan masa nifas dipengaruhi oleh beberapa faktor yaitu umur, pendidikan dan pekerjaan.

Hasil penelitian menunjukkan bahwa sebagian dari responden yaitu $(50,0 \%)$ melakukan kunjungan nifas secara teratur dan sebagiannya lagi tidak melakukan kunjungan nifas secara teratur $(50,0 \%)$. Artinya setengah dari ibu nifas tidak teratur melakukan kunjungan masa nifas sesuai program dan kebijakan pemerintah pada masa nifas.

Menurut hasil penelitian James Lwelamira (2015), mengatakan wanita dengan berpendidikan menengah lebih 
cenderung menggunakan layanan PNC (Postnatal Care) dibandingkan dengan mereka yang tidak memiliki pendidikan formal. Demikian juga, wanita dari keluarga berpenghasilan tinggi lebih cenderung menggunakan layanan. Sedangkan hasil penelitian menurut Fikirte Tesfahun (2014), alasan ibu nifas tidak melakukan pemeriksaan PNC dengan alasan kurangnya waktu, jarak yang jauh ke fasilitas kesehatan, dan kurangnya pelayanan dari fasilitas kesehatan.

Fenomena yang terjadi di masyarakat kunjungan nifas jarang dilakukan hingga tiga kali kunjungan, seringkali hanya dua kali atau bahkan satu kali kunjungan saja selama masa post partum, selama tidak ada keluhan pada ibu maupun bayinya. Selama kunjungan masa nifas tidak dilaksanakan secara teratur maka dapat menimbulkan keterlambatan deteksi terhadap komplikasi dan akan memperlambat penanganannya. Responden penelitian ini tidak melakukan kunjungan nifas sebanyak tiga kali dengan alasan biaya, waktu, dan pekerjaan.

Kunjungan nifas merupakan kunjungan yang dilakukan ibu nifas ke tenaga kesehatan selama masa nifas yaitu dimulai 6 jam sampai 42 hari pasca bersalin oleh tenaga kesehatan (Depkes RI, 2009). Program dan kebijakan teknis pada masa nifas paling sedikit melakukan kunjungan nifas sebanyak tiga kali, karena tujuan kunjungan pada masa nifas adalah untuk mendeteksi secara dini komplikasi pada ibu nifas. Adapun frekuensi kunjungan nifas yaitu kunjungan nifas pertama dilakukan pada 6 jam sampai 3 hari setelah persalinan, dan kunjungan nifas kedua dalam rentang waktu 4-28 hari setelah persalinan, kunjungan nifas ke tiga dalam rentang waktu 29-42 hari setelah persalinan (Depkes RI, 2009).

Hasil uji statistik menunjukkan adanya hubungan antara pengetahuan ibu nifas tentang materi perawatan masa nifas dalam buku KIA dengan kunjungan nifas. Responden yang memiliki pengetahuan baik tentang perawatan masa nifas banyak memperoleh informasi melalui buku KIA, yaitu dengan membaca buku KIA.

Pengetahuan tentang perawatan masa nifas dalam buku KIA yang baik akan membentuk suatu tindakan atau perilaku positif. Seseorang dengan pengetahuan yang cukup dapat menerapkan apa yang ia tahu kedalam pelaksanaan di kehidupan sehari-hari, sehingga perilaku yang baik akan kesehatan khususnya mengenai perawatan pada ibu masa nifas (Dewi, 2011). Responden penelitian ini sebagian besar hanya memiliki latar belakang pendidikan tamat SMP atau sederajad, sehingga tingkat pengetahuan mereka tentang materi perawatan masa nifas dalam buku KIA pun sebagian besar berada pada tingkat cukup dan kurang. Di samping itu, pemanfaatan buku KIA oleh ibu dan keluarga masih rendah dan memerlukan studi lebih lanjut. Di antara responden dengan pengetahuan yang kurang baik, sebagian kecil responden tidak melakukan kunjungan nifas dengan teratur sebesar $(31,3 \%)$ dibandingkan dengan pengetahuan yang baik, sebagian kecil dari mereka melakukan kunjungan nifas secara teratur yaitu sebesar $(28,1 \%)$. Hal ini menunjukkan bahwa pengetahuan cukup berpengaruh terhadap perilaku seseorang yang menandakan pengetahuan berhubungan dengan tindakan atau perilaku seseorang dalam menyikapi kehidupan sehari-hari khususnya bagi ibu nifas dapat menerapkan pengetahuan 
tentang cara perawatan masa nifas. Oleh karena pengetahuan ibu yang kurang mengenai jenis-jenis pelayanan yang akan mereka peroleh saat melakukan kunjungan nifas, maka menyebabkan keinginan untuk melakukan kunjungan nifas menjadi rendah pula. Umumnya ibu nifas hanya melakukan kunjungan atau kontrol pada waktu 6 hari setelah persalinan saja, selanjutnya mereka tidak melakukan kunjungan berikutnya apabila tidak mengalami keluhan pada diri maupun bayinya.

Hasil penelitian ini mendukung hasil penelitian yang dilakukan oleh Lwelamira dan Tesfahun yang menjelaskan bahwa pemanfaatan pelayanan kesehatan masa nifas dipengaruhi oleh beberapa faktor, yaitu: pengetahuan, persepsi, jarak antara tempat tinggal dan fasilitas kesehatan, waktu yang dimiliki, serta otonomi yang dimiliki oleh ibu nifas.

Dari uraian tersebut dapat ditarik kesimpulan bahwa ibu nifas dengan pengetahuan yang baik maka kemungkinan ibu akan melakukan kunjungan nifas sesuai dengan program pemerintah, meskipun masih ada faktor lain yang perlu diperhitungkan dalam mempengaruhi keteraturan ibu dalam melakukan kunjungan nifas.

\section{KESIMPULAN DAN SARAN}

Pengetahuan ibu nifas tentang materi perawatan masa nifas yang terdapat dalam buku KIA sebagian besar berada pada distribusi cukup dan kurang. Ibu nifas yang melakukan kunjungan nifas secara teratur dan tidak teratur berada pada proporsi yang sama. Hasil uji hipotesis secara statistic menunjukkan adanya korelasi antara pengetahuan ibu nifas tentang materi perawatan masa nifas dalam Buku KIA dengan keteraturan kunjungan nifas. Ibu nifas yang memiliki pengetahuan baik tentang materi perawatan masa nifas dalam buku KIA cenderung melakukan kunjungan nifas secara teratur sesuai program pemerintah, dan sebaliknya.

\section{DAFTAR RUJUKAN}

Arikunto S, 2006, Prosedur Penelitian Suatu Pendekatan Praktik: Edisi Revisi VI, Jakarta, PT Rineka Cipta Buhari, IS, Hutagaol, E, 2015, Hubungan Tingkat Pengetahuan Dengan Mobilisasi Dini Pada Ibu Nifas, Program Studi ilmu Keperawatan Fakultas Kedokteran Universitas Sam Ratulangi Manado

Departemen Kesehatan RI, 2012, Pedoman Pemantauan Wilayah Setempat Kesehatan Ibu dan Anak, Jakarta, Departemen Kesehatan RI

Dinas Kesehatan Kota Malang, 2015, Laporan Kinerja Dinas Kesehatan Kota Malang, Malang, Dinas Kesehatan Kota Malang

Departemen Kesehatan RI, 2008, Instrumen Evaluasi Petugas Kesehatan Pasca Orientasi Buku KIA di Tempat Pelayanan, Jakarta, Departemen Kesehatan RI

Departemen Kesehatan RI, 2009, Panduan Manajemen Suplementasi Vitamin A, Jakarta, Departemen Kesehatan RI

Departemen Kesehatan RI, 2008, Kepmenkes Nomor:

828/MENKES/SK/IX/2008 tentang Petunjuk Teknis Standar Pelayanan Minimal Bidang

Kesehatan di Kabupaten/Kota

Dewi, V, Sunarsih, T, 2012, Asuhan Kebidanan Pada Ibu Nifas, Jakarta, Salemba Medika 
Dewi, M, Wawan, A, 2011, Teori dan Pengukuran Pengetahuan, Sikap, dan Perilaku Manusia, Yogyakarta, Nuha Medika

Kementerian Kesehatan RI, 2016, Buku Kesehatan Ibu dan Anak, Jakarta, Kementerian Kesehatan dan JICA Kementerian Kesehatan RI, 2015, Petunjuk Teknis Penggunaan Buku Kesehatan Ibu dan Anak.Jakarta : Kementerian Kesehatan dan JICA Lwelamira, J, Safari, J, Stephen, A, 2015, Utilization of Maternal Postnatal Care Services Among Women in
Selected Villages of Bahi District. Current Research Journal of Social Sciences 7(4): 106-111, 2015 Prawiroharjo, S, 2012, Ilmu Kebidanan, Jakarta, Yayasan Bina Sarwono Prawirohardjo

Tesfahun, F, 2014, Knowledge, Perception, and Utilization of Postnatal Care of Mothers in Gondar Zuria District, Ethiopia: A Cross-Sectional Study. Maternal Child Health_Journal, 2014 Dec; 18(10): 2341-51. doi: $10.1007 / \mathrm{s} 10995-014-1474-3$ 